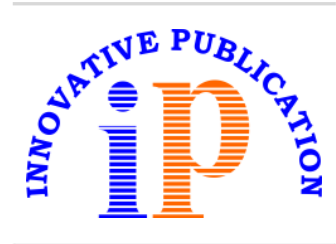

\title{
Editorial
}

\section{Chrono-pharmaceutical approaches to optimize dosing regimens based on the circadian clock machinery}

\author{
Shoheb S Shaikh ${ }^{*}$, Sachin M Kokate ${ }^{1}$ \\ ${ }^{1}$ Dept. of Pharmaceutical Chemistry, Siddhi's Institute of Pharmacy, Nandgaon,, Maharashtra, India
}

\section{A R T I C L E I N F O}

\section{Article history:}

Received 24-11-2021

Accepted 10-12-2021

Available online 05-01-2022
This is an Open Access (OA) journal, and articles are distributed under the terms of the Creative Commons Attribution-NonCommercial-ShareAlike 4.0 License, which allows others to remix, tweak, and build upon the work non-commercially, as long as appropriate credit is given and the new creations are licensed under the identical terms.

For reprints contact: reprint@ipinnovative.com

\section{CORRIGENDUM / ERRATUM / RETRACTION}

This article has been retracted by Publisher based on the following reason:

The Editor-in-Chief about statistical irregularities in this article in December 2021. The Editor-in-Chief thoroughly investigated this article and other preceding papers from the same database. On this basis, the Editor-in-Chief decided to retract the manuscript.

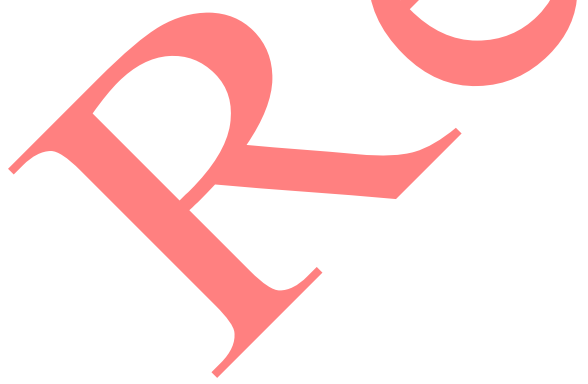

